DOI:10.24193/tras.55E.4

Published First Online: 2018/10/23

\section{IMPACT OF CLUSTER BUILDING \\ IN LABOR INTENSIVE INDUSTRIES \\ ON REGIONAL ECONOMY \\ (WESTERN ROMANIA)*}

\section{Claudia POPESCU}

\author{
Claudia POPESCU \\ Professor, Department of Tourism and Geography, \\ Faculty of Business and Tourism, \\ Academy of Economic Studies, Bucharest, Romania \\ E-mail: cldpopescu@yahoo.com
}

Abstract

Starting with the mid-1990s, the Western Romania footwear cluster has emerged and grown attaining a critical mass of producers and suppliers. Statistical data analysis based on Location Quotient (LQ) supports the relative concentration of firms and jobs in the footwear cluster as compared to the rest of the regions. The higher $L Q$ values of firms are positively correlated with high levels of entrepreneurship and qualified and diversified labor pool, whereas the high $L Q$ of footwear employment shows the large scale production at region-industry level. Better performance of the firms in the cluster is revealed by much higher averages of turnover, size and profit as compared to the national average. Along the process of cluster building, the composition of the firms has turned hierarchical by functions, and diverse by size and production capabilities. Therefore, the cluster has gradually made the transition from a low-tech, labor intensive manufacturing to a local production system based on skills, knowledge and end-of-line activities. The findings of the paper reveal the impact of the cluster building on the regional economy in terms of specialization, competitiveness, integration into the global supply chain, and spatial pattern. Finally, the analysis will provide insights into the relations between the footwear cluster, regional development and policy design.

Keywords: relocation of production, cluster building, footwear industry, Western Romania, Italy.
* Acknowledgement. This research is part of a larger project of IGAR on 'Regional Geographical Studies in the view of Sustainable Development and Trans-sectoral Cooperation', 2017. Special thanks are due to Mihaela Persu for drawing the maps and to the anonymous referee for useful comments and suggestions. 


\section{Introduction}

Starting with the 1990s, transition economies have been characterized by emerging clusters in a variety of industries, from traditional to high-tech, as a result of both the delocalization of industrial supply chains across Europe (European Commission, 2001-2004) and increasing domestic entrepreneurship. One of the industrial sectors that have shifted from the Western to Eastern Europe is the footwear industry. Within the process, Italy and Romania have played a central role due to two major triggering events which have contributed to the creation of new productive networks: the relocation of Italian producers and the openness of the Romanian economy to trade and foreign investments. On the one side, the market pressure from low-cost producers in Asia, in particular China, has forced many Italian footwear firms to relocate part of their production in Romania. Consequently, Romania has become the $3^{\text {rd }}$ supplier of footwear to the EU market in early 2000s (European Commission, 2005).

On the other side, there are several prerequisites which explain the relocation of Italian firms to Romania. First, the country is traditionally specialized in the footwear industry. In 1990 the leather and footwear industry numbered more than 125 thousand jobs employed, mainly, by large state-owned enterprises. Romanian integration with the international economy required a period of catching up which involved a deep restructuring of production and labor markets. In the first half of the 1990s, many leather and footwear firms closed down and 43.5 thousand jobs were lost nation-wide. Therefore, availability of skilled and cheap labor played a crucial role in attracting Italian shoe producers. Proximity, both in geographical and cultural terms, mainly accessibility and short distance from Italy were important incentives for Italian relocation. The advantages relative to labor and transport costs were complemented by institutional factors like European funding for joint ventures in Central and Eastern European Countries (CEECs). One other particular reason for Italian firms to relocate to Romania refers to the easy flow of information on delocalization opportunities provided informally by the large Romanian community settled in northern Italy in the aftermath of the 1990s political changes. There are other reasons as well, such as the more relaxed environment protection laws, flexible regulations concerning work, incentives for foreign investors and exporting companies, and the low rate of unionization (Mariotti and Montagnana, 2008; Constantin et al., 2006). Additionally, external factors have enhanced the attractiveness of the western region for Italian investments. The openness of the economy to trade and foreign investments in early 1990s brought to a sudden end the decades of inward-oriented policies of industrialization. The shift in the location of the manufacturing activities has involved a spatial decentralization of employment, as industry moved from autarky industry location centers, mainly internal regions, to a number of locations with a better access to the European Union markets. These macro-scale shifts have triggered economic growth of the Western Romanian Region as a border region.

The potential of the footwear industry to grow and cluster in the Western Region has been acknowledged by several national (Russu, 2003; Asociația pentru Studii și 
Prognoze Economico-Sociale, 2010; Popescu, 2010) and international studies (Industrial Cluster Development, 2003-2004; European Commission, 2001-2004). According to these studies, the footwear cluster in Arad-Timişoara was made up of more than 300 companies and 32 thousand employees in 2001. In 2007, in Timişoara there were 420 Italian companies registered, with a capital of more than 2 million euro, which placed Italy on the first rank in number of foreign companies and in the second in invested capital (Timişoara City Hall, 2008, p. 54).The agglomeration of footwear producers in Timişoara included more Italian producers than Romanian (Montagnana, 2005) and the region turned to be known as 'the eighth province of Veneto' (Isbasoiu, 2006). The concentration of footwear firms is also significant in Bihor county which totalized 202 companies and 13,794 employees in 2009 (Cojanu et al., 2010). The Italian presence is widely spread throughout Romania, but in late 1990s there has been noticed a trend of concentrating in certain regions; the largest number of Italian investors is found in the West of Romania and especially in Timişoara (Ferrari, 1999).

Recent research was focused on the impact of delocalization on the origin Italian districts in terms of labor and economic performance. While extensively focused on the Italian districts, these studies marginally discuss the impact of the relocation process on the host economy. In that context the aim of this paper is to shift the focus of the analysis on the economic impact of the emerging concentration of footwear producers in Western Romania. The paper adopts a developmental perspective examining the economic development implications of delocalization and cluster building at regional level. To accomplish this aim, the paper is structured in several sections.

Firstly, the role of Italian relocation on cluster building is discussed based on the findings of the extant literature. Secondly, the spatial concentration of footwear firms based on quantitative methods (Location Quotient analysis) is aiming to reveal the specialization of the regional economy. Thirdly, the composition of the cluster suggests the evolutionary patterns of selection and change which triggered the diversification of productive capabilities, higher integration into the global supply chain and spatial pattern. Finally, policy recommendations are outlined.

\section{Literature review}

After 1990, under strong internationalization pressure, Italian footwear firms searched to benefit from labor cost differentials by relocating in Central and Eastern Europe. The relocation of their productive activities was mainly driven by 'efficiency-seeking' reasons (Farshchi, 2008), meaning lower costs of production and cheaper labor. Pursuing international outsourcing and aiming to reduce production costs, Italian firms have gradually transferred to Romania the bottom phases of the production process, developing a 'buyer-driven value chain' (Isbasoiu, 2006). All along the 1990s, Romania became the preferred location for final processing in footwear industry (Cutrini, 2003; Amighini and Rabellotti, 2006; Sammarra and Belussi, 2006). Firms from Italian footwear districts relocated to Western Romania in successive waves. The Montebelluna district moved massively low value added production stages to 
Romania hosting $46 \%$ of FDI and $62 \%$ of international subcontracting in Eastern European countries (Sammara and Belussi, 2006). Firm relocation from Marche district contributed mainly to the creation of a twin local productive system in Arad-Timiș (Cutrini, 2011). Also Verona firms relocated final producers in the Western part of Romania, except in 1997 and 2000, which suggests that it might have started to diversify its partner countries (Amighini and Rabellotti, 2006). Brenta switched to Romania in 1999, importing more than 75\% of footwear as outward production trade in 2000.

Much of the extant literature focuses on the driving forces of relocation. The Italian industrial districts (IDs) are dominated by small and medium-sized enterprises (SMEs) with organizational structure based on subcontracting relations inside the vertically disintegrated productive chain. These firms form closed SMEs systems which traditionally interact with the exterior through the two ends of the value chain. Facing the crisis of Fordism and the challenges of globalization, these firms broke the 'tacit agreement' that had bound them together in their origin districts and started to delocalize. The delocalization process was based on initiatives taken at firm level as Italian firms took advantage of the openness of the Central and Eastern European countries in their pursuit for profit. The mix of strategies employed by the Italian firms shows their attempt to overcome uncertainties. Italian companies have relocated production activities in Romania through foreign trade, cooperation agreements and direct foreign investments. The cooperation agreements were dominant in the 1990s; on their basis, Italian companies were exporting raw materials and intermediate products to Romanian subcontractors who processed them in finished items and exported them back to Italy. These cooperation agreements decreased drastically after 2000 and were replaced with foreign direct investments (Mariotti et al., 2008).

Another significant part of the literature is devoted to the study of the self-augmenting processes of the cluster building in the region of destination. The delocalization process was mainly based on 'vertical investments' (Majocchi, 2000) through which district firms have migrated along with their suppliers and trustful collaborators searching to reduce the risk of losing crucial sources of 'tacit knowledge' and accumulated competences embodied in skilled workers and managers (Sammarra and Belussi, 2006). The Italian entrepreneurs employed two major forms of delocalization mechanisms: the 'imitation effect' and the 'district effect' (Isbasoiu, 2006). According to the first mechanism, the pioneer firms which first moved to Romania were 'success stories' and triggered a migration process of other district firms. According to the second mechanism, small companies followed the leader-companies in order to keep up the collaboration relations and to reduce the uncertainties by maintaining their membership in the production network. The small companies, once settled in Romania, extended their production and became leaders of the emerging cluster (Majocchi, 2000). The Italian SMEs borrowed the model of production decentralization, usually, pursued by multinationals, holding the strategic marketing activities, business relationship management, design, research-development and prototypes (Sammarra and Belussi, 2006), while the basic production was moved to Romania. Besides 
the leader-companies from the core of the production networks that took advantage of the delocalization, firms playing a marginal role inside the Italian district replicated the logic of the district and the behavior of leader-companies. After relocation, these companies maintained their strategic relationships with partners from Italy and took the lead in the district of destination. By maintaining the relationships with the Italian district, on the one hand, and gradually developing the internationalization process on the other, companies diminished the risks and uncertainties concerning decision-making and access to information. At the end of the 1990s, the agglomeration of firms became stable and created external economies that led to a cumulative process of cluster building.

Italian firm relocation has fostered the emergence of a network of Romanian subcontractors; they are bound by supplying relationship coordinated by the Italian firms (Majocchi, 2000). Leader-companies put their supplier networks in a competition concerning prices and product quality standards, but this competition is placed in a context of intense collaboration as well. Close relationships bring advantages to both sides: the leader-companies can keep the quality standards in line with the market demand, and subcontractors are able to rely on the market outlet thanks to the stable relationship with the leader-company.

A detailed survey of footwear firms in the emerging cluster (Mariotti and Montagnana, 2008) has identified the way in which they were created: $37.7 \%$ through Italian investments, $35.5 \%$ through entrepreneurial spin-off, $16.6 \%$ through relocation and $11.1 \%$ through the privatization of former Romanian state owned enterprises (SOEs). Almost half of the companies are the result of the production internationalization process from the Italian north-eastern district. The intense agglomeration of companies in the 1990s has induced strong local competition, which generated innovation and entrepreneurship. More than a third of the companies were the result of entrepreneurial spin-off and showed that the initial lack of organizational and entrepreneurial resources implying Italian management has been gradually overcome.

The motivation for internationalization influences the mechanisms of relocation and the affiliates of efficiency-seeking 'small multinationals' while focusing on costs does not interact with the local environment in destination countries as to trigger development based on knowledge transfer. Relocation, was not aiming to fully replicate the district model: it has created a second layer of subcontractors that are dispersed across the Western Region (Farshchi, 2008). Recent studies pinpointed that knowledge sharing and business relations are eased by spatial proximity, but organized in selective network configurations, co-located firms might not share much or even be unrelated (Ferloni, 2010). Anyway, the emerging networks of producers are held together by an increasing stability of relationships between the lead and the subcontracting firms as substitution of subcontractors with corresponding skills and productive capacity is not easily accomplished on short term. Therefore, long lasting relations were not typical of the cluster in its infancy (Farshchi, 2008), but they are frequent in recent years of growth (Cutrini, 2011). 


\section{Research methodology}

The data used to assess the footwear cluster in the Western Region, comprising the counties of Arad, Bihor and Timiş, are sourced from two nation-wide statistical databases: the National Institute of Statistics for aggregated data at county level and Lista Firmelor din România for data at firm and NUTS V level. The statistical and spatial analysis based on 4-digit CANE Rev. 1 (1930 - sector manufacturing of footwear) up to 2008 and CANE Rev. 2 data (1520 - sector manufacturing of footwear) after 2008 is aiming to identify the geographical concentrations of footwear firms at the national level. These firms provide the core activities of the emerging clusters, therefore their spatial pattern helps the understanding of the relationships between territorial capabilities, footwear industry development and regional economies. High concentration of footwear firms and employment mirrors the level of regional specialization and it is measured by the Location Quotient (LQ) in 2007, 2012 and 2015.These years are relevant for the analysis as they represent the year before the onset of the economic crisis (2007), the beginning of the economic rebound after the crisis (2012), and the latest data recorded by the national statistics (2015).

Location Quotient is a method of quantifying the level of concentration of a particular industry in a region as compared to the nation. It is a ratio that compares a region to the larger reference national average, in terms of the number of firms and employment, identifying the export-oriented industries in a region. Typically, LQ is calculated as a ratio of regional firms and jobs in industry I in year $\mathrm{T}$ and total regional firms and jobs in year $\mathrm{T}$ as compared to the ratio between national firms and jobs in industry I in year T and total national firms and jobs in year T. LQ is used to determine the export-oriented industries in a region which provide jobs and bring wealth. Industries which have both high LQ and relatively high total job numbers typically form the region's economic base.

In our case, the above average values of LQ of footwear firms suggest high levels of entrepreneurship and qualified and diversified labor pool capable to generate informational spillovers, whereas the high values of employment shows the large scale footwear activities at region-industry level.

Data at firm level are filtered by sector and location from the nation-wide database (Lista Firmelor din Romania) and used to GIS mapping of the spatial pattern of the footwear industry in 2012 which marked the end of the economic crisis, therefore it retains the firms resilient to the crisis and with stronger capabilities to further develop. These firms are able to react to changes in market demand and likely to develop new products or process technologies. The role of the cluster in creating jobs and enhancing firm capabilities is assessed in terms of size and performance at the regional level as compared to the national. The characteristics of the cluster are derived through statistical sampling analysis of data at firm level filtered by size, turnover and profit, and capital origin. The sample contains the footwear firms which have registered complete data on economic and financial indicators. They represent significant shares of the footwear firms in the Western Region supporting a reliable evaluation of their characteristics. 


\section{Findings and discussion}

The impact assessment of the cluster on the regional economy starts from the identification and validation of the spatial concentration of footwear firms in the region and continues with the analysis of the structure of firms and employment in terms of evolutionary patterns, heterogeneity and functional capabilities. The impact is revealed by the contribution of the cluster to regional competitiveness and international trade and spatial expansion of productive linkages.

\subsection{Higher specialization of the regional economy in footwear production}

At the time of Italian firms' arrival, the national context was characterized by a difficult economic restructuring and shrinking job markets. The peak of Italian relocation from 1997 to 2003 (Crestanello and Tattara, 2011) contributed significantly to rising employment and number of firms in the absence of high local entrepreneurship. The geography of the footwear industry has radically changed both as a result of FDI location and former SOEs restructuring. The number of footwear firms has grown constantly from early 1990s to 2005 and has declined slowly afterwards. In 2012 when the crisis was over, the footwear firms numbered 1,196 at the national level (National Institute of Statistics) and showed a concentrated pattern which clearly distinguishes the Western Region as the most important cluster made up of almost one third of the total number of footwear firms in the country. The cluster is not localized in a continuous territorial concentration but it is articulated in three main local poles within the same region. Despite the losses caused by the shift to long distance delocalization of Italian firms and the economic crisis, the cluster has acquired a critical mass of producers and suppliers numbering 363 firms across the region in 2012 (National Institute of Statistics). A quarter of the foreign-owned firms in footwear industry at the national level are located in the region (Lista Firmelor din România, 2012).

Italian firms' relocation helped the successful transition from large scale enterprises to a production system dominated by SMEs with a significant contribution to new job creation. Italian FDI and the subsequent networking of local suppliers helped to keep up the specialization level in footwear industry of the region. The number of jobs shows a considerable growth, varying from 21,298 in 1997 to a maximum of 42,537 in 2002, meaning that creation of jobs triggered by Italian firm relocation succeeded to offset the sharp decline encountered by former state enterprises. The changes in the strategy of Italian firms and the economic crisis have caused the decline of jobs to figures similar to the beginning of cluster building (21,129 jobs in footwear industry in 2015) according to the National Institute of Statistics. Anyway, the share of regional footwear employment in the total national is $42.65 \%$ in 2015 . The concentration of the footwear firms in the region is mirrored by the constantly rising share in the total national even after Italian firms started to gradually delocalize or during the economic crisis. From $20 \%$ in the early 1990s, the footwear firms in Western Romania account for $29.54 \%$ of the total number of firms at industry level in 2015. Spillovers, associated with technological/knowledge transfer, tend to be geographically localized in the 


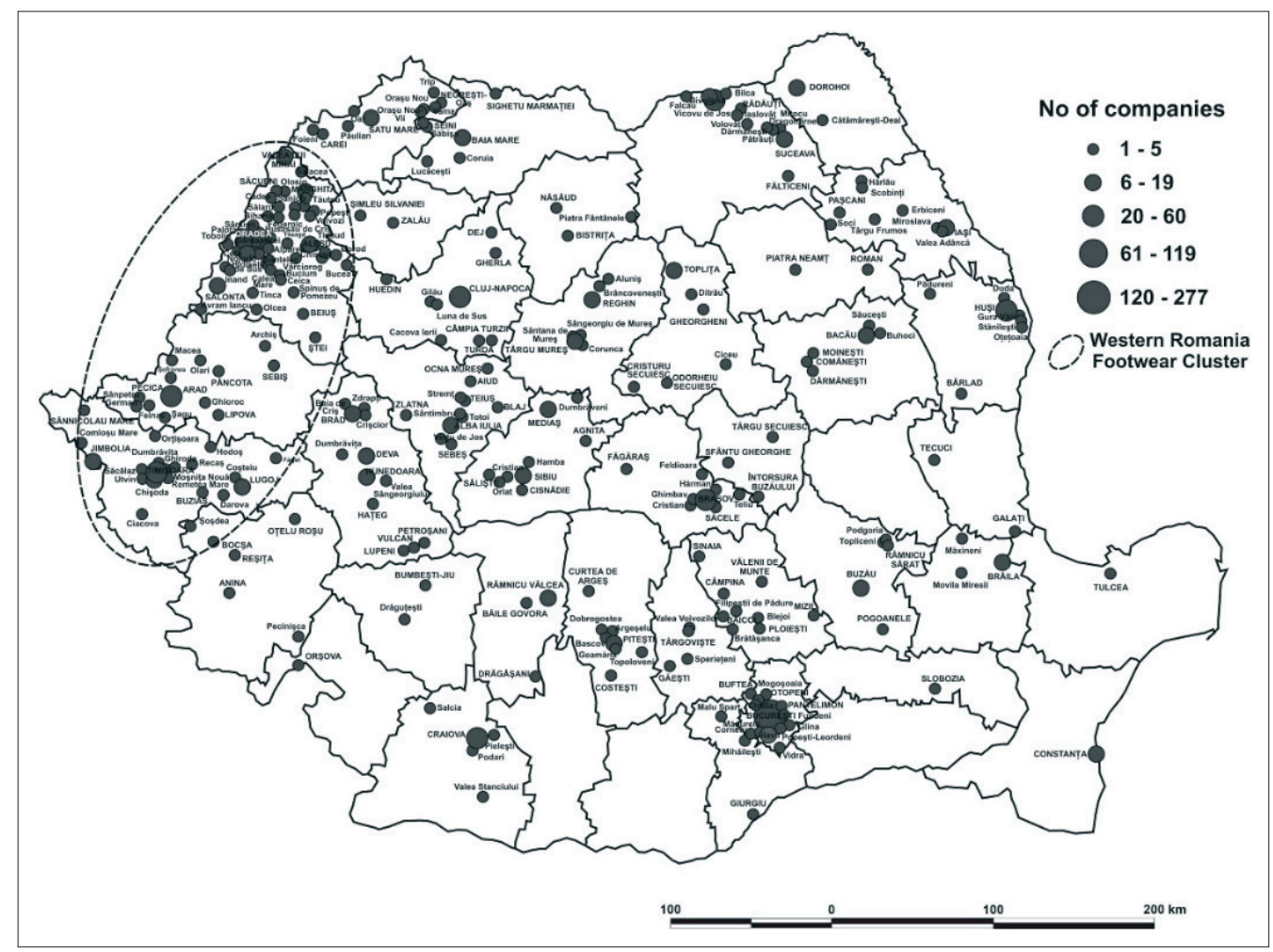

Figure 1: The spatial pattern of footwear firms

Source: Lista Firmelor din România database, 2012

region. Therefore, the region accumulated sources of positive externalities crucial for the further development of the cluster based on attraction and support of innovators. The arrival of Italian firms and the emergence of a regional production network enhanced the level of trust and attractiveness of the business environment for further investments. The presence of Multinational Enterprises (MNEs) reflects an interest to tap into the knowledge bases of the region.

The level of regional specialization in footwear industry is statistically evidenced by the Location Quotient which shows the highest values of relative concentration of footwear manufacturers in the cluster as compared to the rest of the regions (Table 1). In the region the footwear firms are three times more concentrated as compared to the national average, whereas the employment is four times more concentrated. Moreover, the values of LQ remain high for the entire period, before and after the onset of the economic crisis, indicating that the Western Region is a net supplier of footwear products.

The variation of the LQ values shows the evolutionary pathways of firms and employment at regional level; the LQ of footwear firms has slightly increased suggesting the potential to grow of the clustered firms. On the other side, the LQ of footwear employment which has recorded a decrease during the 2007-2015 period shows the 
Table 1: Location Quotient of firms and employment of footwear industry

\begin{tabular}{lccccccc}
\hline & \multicolumn{5}{c}{ Location Quotient } \\
\cline { 2 - 7 } & \multicolumn{3}{c}{ Firms } & \multicolumn{3}{c}{ Employment } \\
\cline { 2 - 7 } & $\mathbf{2 0 0 7}$ & $\mathbf{2 0 1 2}$ & $\mathbf{2 0 1 5}$ & $\mathbf{2 0 0 7}$ & $\mathbf{2 0 1 2}$ & $\mathbf{2 0 1 5}$ \\
\hline Arad County & 2.18 & 1.84 & 1.64 & 1.90 & 1.44 & 1.20 \\
Bihor County & 4.87 & 5.67 & 5.41 & 6.90 & 8.57 & 8.24 \\
Timiș County & 1.63 & 1.71 & 1.74 & 3.54 & 2.89 & 2.56 \\
Western Romania & $\mathbf{2 . 8 6}$ & $\mathbf{3 . 0 8}$ & $\mathbf{2 . 9 7}$ & $\mathbf{4 . 2 7}$ & $\mathbf{4 . 3 0}$ & $\mathbf{3 . 9 9}$ \\
Rest of the Regions & $\mathbf{0 . 7 9}$ & $\mathbf{0 . 7 7}$ & $\mathbf{0 . 7 8}$ & $\mathbf{0 . 6 3}$ & $\mathbf{0 . 6 2}$ & $\mathbf{0 . 6 4}$ \\
\hline
\end{tabular}

Source: National Institute of Statistics

selection and adaptation process at region-industry level. Anyway, the over-representation in terms of employment in comparison with the rest of the regions suggests that the footwear industry represents a major part of the region's economic base. According to the high values of $L Q$, the footwear industry is export-oriented and vital to the region's economy. Firms in Western Romania performed better during the crisis than the footwear firms outside the cluster demonstrating a stable and competitive network of suppliers and manufacturers and playing the role of major employer in the region. The employment of footwear industry accounts for $4.29 \%$ of total manufacturing employment in the region, a share significantly higher than the national, 1.07\% in 2015 (National Institute of Statistics). The economic rationales driving the relocation process have changed from cheap labor and proximity to Western European markets to skilled labor and production infrastructure built through major and long term investments. The trend of enhancing the regional specialization suggests that the cluster has successfully passed through a phase of constant mutation and adaptation and is reaching the phase of stabilization, though in a much reduced and restricted form. The cluster might remain in this state for an extended period of time, as the remaining firms survive by upgrading products or focusing on niche market segments. Additionally, the firms could enlarge their shares of the domestic market.

Inside the cluster, there are significant differences among the three local poles of footwear production in terms of their composition and evolutionary trends. The hard core of the cluster is represented by the county of Bihor with the highest concentration of firms and employment. The positive variation of LQ values suggests that the local system of footwear producers is less vulnerable to external shocks. On the contrary, the other two poles, Arad and Timiş counties have registered negative trends of LQ values due to internal threats (structural rigidities) as well as external threats (economic downturn, technological changes and cluster competition effects).

\subsection{Enhanced regional competitiveness}

Better performance of the firms in the cluster is revealed by much higher averages of turnover, size and profit as compared to the national average (Table 2). The relocation of Italian firms and the enhanced entrepreneurship set in motion the process of knowledge transfer and technological upgrading based on trust building and in- 
cremental learning. Higher average turnover is supported by the solid position of the Italian shoemakers in the international market and the stable relationships between the lead firms and the subcontractors in the cluster. Another source of competitiveness gain is related to the evolution of the cluster from low-value added activities to the entire production cycle.

While in mid-1990s local production was largely confined to basic manufacturing and assembly activities, by the mid-2000s the shift of the entire production process by Italian firms towards Romanian subcontractors was completed as argued by the literature. Almost half of the turnover of the footwear industry is produced by the cluster's firms as a result of structural and technological change. The average turnover of the cluster is about two times higher than that of the rest of footwear firms as result of the constant adaptation process based on high rates of spin-offs and diversification of production capabilities. Higher average profit than at the national levels mirrors the functional upgrading of firms and acquired skills of labor based on technological and knowledge transfer during the process of cluster building and maturation.

Although showing a decrease after 2007, the profit of the cluster remains high and shows the cumulative effects of the cluster building. The bigger size of firms is a result of the rationale behind the delocalization process and the inherited characteristics of the host regional economy. The recent decline in scale of the cluster's firms is due to the onset of the economic downturn in Europe given the strong dependence of the cluster on the European market as well as the rise of major non-European competitors.

Table 2: The characteristics of the footwear regional cluster vs. national

a) 2007

\begin{tabular}{lrrc}
\hline \multicolumn{1}{c}{ Footwear Industry } & Romania & Western Romania & $\begin{array}{c}\text { Cluster share } \\
\text { in total (\%) }\end{array}$ \\
\hline Total number of firms & 1,624 & 466 & 28.69 \\
The sample - Number of firms & 704 & 186 & 26.42 \\
- Employment & 39,879 & 16,672 & 41.80 \\
- Turnover (RON) & $2,327,979,646$ & $1,194,288,853$ & 51.30 \\
- Profit (RON) & $95,539,516$ & $44,232,472$ & 46.29 \\
Average turnover (total turnover/number of firms) & $3,306,789.26$ & $6,420,907.81$ & - \\
Average size (employment/number of firms) & 56.64 & 89.63 & - \\
Average profit (total profit/number of firms) & $135,709.63$ & $237,808.98$ & - \\
\hline
\end{tabular}

b) 2015

\begin{tabular}{lrrc}
\hline \multicolumn{1}{c}{ Footwear Industry 2015 } & Romania & Western Romania & $\begin{array}{c}\text { Cluster share } \\
\text { in total (\%) }\end{array}$ \\
\hline Total number of firms & 1,215 & 359 & 29.54 \\
The Sample - Number of firms & 1,079 & 289 & 26.78 \\
$-\quad \quad$ Employment & 43,175 & 17,783 & 41.18 \\
$-\quad$ Turnover (RON) & $4,172,873,258$ & $2,019,034,973$ & 48.38 \\
$-\quad$ Profit (RON) & $234,747,592$ & $89,849,411$ & 38.27 \\
Average turnover (total turnover/number of firms) & $3,867,352.41$ & $6,986,280.18$ & - \\
Average size (employment/number of firms) & 40.01 & 61.53 & - \\
Average profit (total profit/number of firms) & $217,560.32$ & $310,897.61$ & - \\
\hline
\end{tabular}

Source: Total number of firms (National Institute of Statistics) and the sample (Lista Firmelor din România) 


\subsection{The layered regional production system with diversified capabilities}

The relocation of Italian firms opened the way for other FDIs from Germany, Austria, Luxembourg, Switzerland, and Spain to locate into the region. Attraction of FDIs and the growing number of domestic suppliers and manufacturers made the contribution of the cluster significant to the growing number of footwear firms at the national level, accounting for $36.5 \%$ of the firms created during the 1997-2007 period (National Institute of Statistics). This trend reversed after the onset of the economic crisis but at lower rates than the national average. The number of Italian firms has remained unchanged lately, 101 in 2012 and 95 in 2015 (Lista Firmelor din România) showing a stabilization process. On the contrary, radical changes have emerged among the Romanian footwear producers: some remained as satellite firms closely related to the Italian manufacturers and caught in captive relations with the customers and retailers; others are independent producers oriented to the Romanian and Eastern European markets. The former benefit from far-reaching production arrangements while the latter are limited to local and regional exchanges, both in terms of input sources and output destination. The cluster comprises different global and local value chains, with complex direct and indirect effects on the development of the cluster.

Along the process, the composition of the cluster has turned hierarchical by functions and diverse by firm size and production capabilities. The cluster is made up of three categories of firms: medium-sized Italian firms following an investment strategy based on labor cost reduction which lessens the pressure for innovation and investments upon companies; small-sized Romanian firms following a survival strategy and less empowered with change-inducing capacity; and MNEs branches and former state-owned enterprises, supplying the international, mostly European markets with high quality products. These firms perform different functions according to various level of innovation and knowledge, and the roles they play inside the cluster, some are suppliers of production inputs, others are manufacturers of finite products and others have integrated production systems.

\subsection{Growing integration into the global supply chain}

The footwear production in Romania has doubled during the peak of the Italian firms' relocation. The national output was 36 million pairs in 1997 and 74 million pairs in 2004. The 'de-delocalization' of Italian firms and the onset of the economic crisis have impacted negatively the output (48 million pairs in 2015) (National Institute of Statistics). All along the period, the exports have increased significantly both in volume and value. Two thirds of the exports are represented by leather shoes and more than half of them reach the Italian market as a result of the relocation process, whereas imports come mainly from China and are dominantly rubber and plastics (www.worldfootwear.com).

Footwear firms in Western Romania are net suppliers of exports. Enhanced competitiveness of the region is primarily sourced from the external links that connect firms in the cluster to Italian Industrial Districts' firms and markets. Additionally, 
some firms have focused on niche or prestige market segments, such as ski boots and mountain footwear which require a relatively advanced technical specialization. The top five exporting firms in the Western Region are subsidiaries of Austrian and German MNEs - Rieker Romania Timiș (Lugoj), Ara Shoes Romania Bihor (Valea lui Mihai), Lloyd Shoes Romania Bihor (Valea lui Mihai) controlled by Otter Distribution Group, and two Italian subsidiaries Coste Shoes Arad (Arad) and Bihore SRL Bihor (Oradea). The first three firms have year to year fluctuations of turnover and profit but relatively stable number of employees after 2012. The last two firms recorded opposite evolutions: Coste Shoes Arad underwent dramatic losses of turnover and employment and negative profit, whereas Bihore SRL Oradea recorded increasing turnover and profit and a stable number of employees (Lista Firmelor din România). Another Italian MNE, Geox, opened a production unit in Timisoara in 2003 (Technic Development) employing 2,800 workers, but in 2009, the factory was sold to another Italian firm (VT Manufacturing) as a result of the reorganization strategy pursued by Geox.

\subsection{Urban-rural integration through production linkages}

The relocation process of Italian firms to Romania was constantly driven by efficiency-seeking mechanisms in terms of production costs. Structural changes in terms of ownership and firm size as well as the FDI location brought about spatial outcomes at regional level. Before 1990, the footwear industry was anchored in few large scale enterprises located as a rule in urban areas. Recent evolution was driven by both branch-plant and diffuse industrialization making rural areas attractive as places of production. The latter has been directed towards the reserves of unskilled labor in peripheral rural areas, while the former has been directed towards the skilled manual labor reserves of declining industrial-urban regions. The consequences of job creation in footwear industry were equally important: on the one side, the enhancement of the manufacturing and entrepreneurial skills of the rural labor and, on the other side, the reduction of the unbalances on the urban labor market due to the massive layoffs of the former state-owned industries.

The spatial distribution of firms results from filtering the firms by location and origin of capital (Lista Firmelor din România database). Footwear firms are spread in 67 urban and rural settlements across the region and form an extended productive network (Figure 2). Along the process of cluster building the labor cost differentials have shifted the activities of production from urban to rural. Therefore, the local economy attains high level of specialization in many of the small and medium-sized towns and rural settlements and, in some cases, the footwear industry is the major employer. One third of the local employment belongs to the footwear industry in Aleșd (Bihor), Marghita (Bihor) and Ghiroda (Timiş) and, in some others the share exceeds two thirds as in Valea lui Mihai (Bihor), Dumbravita (Timiş), and Mosnita Noua (Timiş). The concentration of footwear firms generated in-migration flows of labor and extended the labor market beyond local settlements. In many cases the footwear firms stand for single employer playing a major role in job creation and wealth generation at local level. 
The spatial pattern of distribution is shaped by the co-location of Italian producers and Romanian subcontractors in most of the localities suggesting the creation of local networks of production. Both Italian firms and their Romanian satellites develop strong cooperation linkages inside these networks whereas competition is placed mainly between them. The growing number of Romanian firms shows the recent structural changes inside the cluster with the emergence of independent producers based in the region with much of the inputs sourced locally and significant share of the production addressing the domestic market.
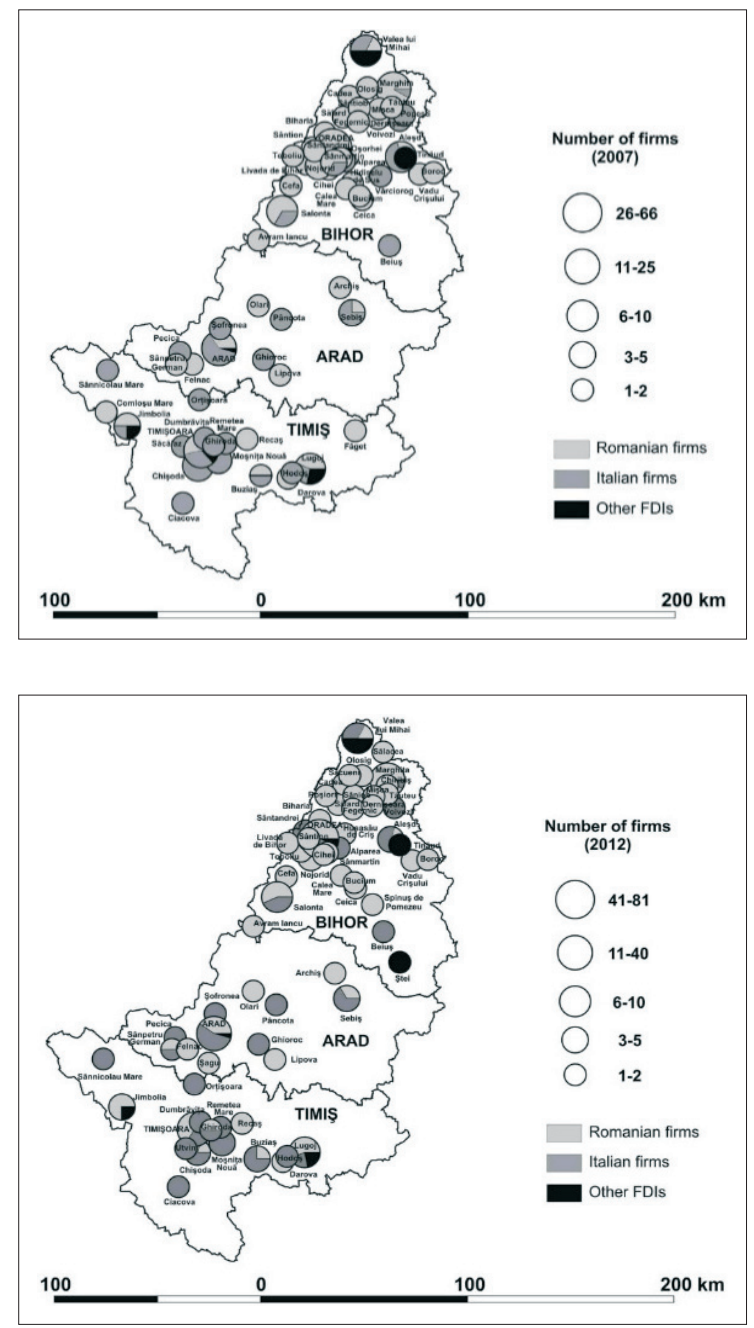

Figure 2: Cluster firms by capital origin

Source: Lista Firmelor din România database, 2012 


\section{Policy recommendations}

Economic policy, less oriented towards competitiveness, did not play any meaningful role in the cluster formation and, therefore, the firms inside the cluster had to operate in a more challenging environment. The cluster consists of many small producers in competition finding difficult to be collectively represented, and the absence of an institutional environment that would help further diffusing the benefits of cluster formation limits the process of upgrading. Nevertheless, small business, although highly fragmented, seemed likely to determine direction to the local economy through communication and informal networks of producers.

In the long run, the advantages of the cluster in terms of proximity to western European markets and abundant and cheap labor has turned into skilled labor, technological upgrading and full range of production capabilities. Enhanced specialization level in footwear production, higher value added activities rooted in the region and the emergence of an increasing number of Romanian independent producers represent the main structural and functional changes that have occurred inside the cluster. The hierarchical composition of the cluster requires a specific cluster-oriented policy. Thus, the main objective should be targeted to the domestic independent producers enabling them to enhance designing, branding and marketing capabilities while improving manufacturing skills. Addressing the national market as well as Eastern European markets represents a good marketing strategy which enhances independent capabilities and avoids the strong competition of the international markets. Producing own brands combined with contract working for international firms could bring strategic benefits by maintaining a certain level of independence. Sales online or group shops explicitly labelled as Romanian shoemakers would allow skipping intermediaries and increasing the revenues. Localized competences of production in the region need constant improvement and adequate incentives for innovative and high value-added activities should be provided by the economic policy. Therefore, supporting institutions (trade associations, industry specific education/training programs) and public agencies capable of mediating relations among the cluster' firms play a major role in strengthening the economic performance and regional competitiveness. The regional development policy should keep the balance between promotion of higher value added sectors rooted in the region (automotive, IT\&C) and the footwear industry, albeit traditional, is competitive and innovative.

The variation of the LQ values of firms and employment adds important pieces of information relevant to policy design. The footwear cluster in Bihor, as the leading pole, represents the strength of the regional economy, and is expected to become more dominant over time if supported by targeted policy measures, while the strong but declining clusters of Arad and Timiş need structural changes to foster upward trends.

\section{Conclusions}

The literature devoted to the delocalization of production from Italian districts to Romania has marginally discussed the impact of the relocation process on the host 
economy. Therefore, the aim of this article was to shift the focus of the analysis on the impact of the footwear cluster on the economic development of the Western Region. The paper contributes to the literature by discussing the patterns of change in clustered industries resulted from the international delocalization of production and increasing entrepreneurship.

Starting with the mid-1990s, the cluster has emerged and grew attaining a critical mass of producers and suppliers. Statistical data analysis supports the relative concentration of firms and jobs in the footwear cluster as compared to the rest of the regions. The higher LQ values of firms are positively correlated with high levels of entrepreneurship and qualified and diversified labor pool capable to generate informational spillovers, whereas the high LQ of footwear employment shows the large scale production at region-industry level.

The arrival of the Italian manufacturers has resulted in upgrading both at industry and region level and opened the door for the location of other FDIs able to capture the external knowledge in addition to inherited local know-how and productive capabilities in a mutually reinforcing mechanism of growth. The share of the region in the total employment, turnover, profit and FDI firms in the footwear industry shows the significant weight of the cluster in the national production system. Italian firms' relocation helped the successful transition from large scale enterprises to a production system dominated by SMEs with a significant contribution to new job creation offsetting the state-owned industry decline. As a result, Italian FDI and the subsequent networking of local suppliers helped to keep up the specialization level in the footwear industry of the region. The spatial spread of footwear firms in a large number of rural and urban settlements of various sizes contributed to the strengthening of their economic basis and enhancing territorial cooperation based on functional networking.

The footwear concentration has gradually made the transition from a low-tech, labor intensive manufacturing to a local production system based on skills, knowledge and end-of-line activities. The share of the Italian FDI remained almost unchanged meaning that during the more recent stages of cluster building, the role of Italian relocation versus entrepreneurship to trigger industry-region growth has been largely reversed and indicating that the initial lack of organizational and entrepreneurial resources implying that Italian management has been gradually overcome. The on-going stabilization of the cluster is supported by the increasing entrepreneurship and less marked dependence on foreign capital inflow. This recent trend might be an opportunity to foster the development path in the region based on collaborative linkages of knowledge and technology sharing in the detriment of the dependency path supported by hierarchical structures and captive relations of production.

\section{References:}

1. Amighini, A. and Rabellotti, R., 'How Do Italian Footwear Industrial Districts Face Globalisation?', 2006, European Planning Studies, vol. 14, no. 4, pp. 485-502.

2. Asociația pentru Studii și Prognoze Economico-Sociale, Grupul de Economie Aplicată, 'Reindustrializarea României: Politici și Strategii' (Romanian Reindustrialization: Pol- 
icies and Strategies), 2010, [Online] available at http://www.minind.ro/studiu_ASPES/ studiu_reindustrializarea_ro_bostina_ok.pdf, accessed on June 21, 2017.

3. Cojanu, V., Pîslaru, D., Pătru-Stupariu, I., Muraru-Ionel, C. and Botezatu, E., 'The Competitive Potential of Economic Growth: Guiding Lines for a New Industrial Policy in Romania', Strategy and Policy Studies (SPOS), no. 4, European Institute of Romania, 2010, [Online] available at https://www.econstor.eu/bitstream/10419/74694/1/655173595.pdf, accessed on June 20, 2017.

4. Constantin, F., de Giusti, G. and Tattara, G., 'Il Decentramento Produtivo in Romania in Tre Distretti del Nord-Est', Studi sull'Economia Veneta, no. 5, 2006, Università di Venezia, [Online] available at https://mpra.ub.uni-muenchen.de/754/1/MPRA_paper_754.pdf, accessed on June 20, 2017.

5. Crestanello, P. and Tattara, G., 'Industrial Clusters and the Governance of the Global Value Chain: The Romania-Veneto Network in Footwear and Clothing', 2011, Regional Studies, vol. 45, no. 2, pp. 187-203.

6. Cutrini, E., 'Evolution of Local Systems in the Context of Enlargement', Sussex European Institute, Working Paper no. 67, Sussex University, Brighton, 2003, [Online] available at https://www.sussex.ac.uk/webteam/gateway/file.php?name=sei-working-paper-no-67.pdf\&site=266, accessed on June 20, 2017.

7. Cutrini, E., 'Moving Eastwards while Remaining Embedded: The Case of the Marche Footwear District, Italy', 2011, European Planning Studies, vol. 19, no. 6, pp. 991-1019.

8. European Commission, 'The Moving Frontier: The Changing Geography of Production in Labor Intensive Industries', 2005, [Online] available at https://cordis.europa.eu/ docs/publications/9061/90619061-6_en.pdf, accessed on June 21, 2017.

9. European Commission, West-East Industrial Districts (WEID), $5^{\text {th }}$ Framework Program, 2001-2004.

10. Farshchi, M.A., 'Evolutionary Patterns and Strategies for Internationalization and Relocation: Industrial Districts and Productive Capabilities in Europe', paper presented at $34^{\text {th }}$ EIBA Annual Conference, Tallinn, Estonia, December 11-13, 2008.

11. Ferloni, A., 'Who Is Making Your Shoes? The Localization of Footwear Production Networks in Timiș County', Master Thesis, Utrecht University, 2010.

12. Ferrari, R.M., 'Small Enterprise Clusters for Local Development in Transition Context: The Case of Romania', Bocconi University, Milan, 1999, [Online] available at http:// www.marcoferrari.net/materiali/SME_clusters_for_local_development_of_Romania. pdf, accessed on June 19, 2017.

13. Industrial Cluster Development (INCLUD), Interreg IIIB - Cadses, 2003-2004.

14. Isbasoiu, G.M., 'Industrial Clusters and Regional Development. The Case of Timişoara and Montebelluna', MPRA Paper no. 5037, 2006, [Online] available at https://mpra. ub.uni-muenchen.de/5037/1/MPRA_paper_5037.pdf, accessed on June 19, 2017.

15. Majocchi, A., 'Are Industrial Clusters Going International? The Case of Italian SMEs in Romania', Working Paper no. 12, Insubria University, Faculty of Economics, 2000, [Online] available at http://eco.uninsubria.it/dipeco/Quaderni/files/QF2000_12.pdf, accessed on June 19, 2017.

16. Mariotti, J. and Montagnana, S., 'Italian Investments in the Agglomeration of Timişoara in Romania: Threat and Opportunity for the Economic Development', 2008, Romanian Journal of Regional Science, vol. 2, no. 2, pp. 33-59. 
17. Mariotti, S., Mutinelli, M. and Piscitello, L., 'The Internationalization of Production by Italian Industrial Districts' Firms. Structural and Behavioural Determinants', 2008, Regional Studies, vol. 42, no. 5, pp. 719-735.

18. Montagnana, S., 'Delocalization and Economic Development: Is Timişoara a Cluster? A Preliminary Study of the Footwear Industry', paper presented at the Micro and Macro Dynamics in the Development Process Seminar, Varese, Italy, 2005.

19. Popescu, C., 'Industrial Clusters and Regional Development in Romania', 2010, Human Geographies Journal of Studies and Research in Human Geography, vol. 4, no. 2, pp. 17-34.

20. Russu, C., 'Politica industrială a UE și a României - convergență și competitivitate' (Industrial Policy of EU and Romania - Convergences and Competitivity), in ***, Dezvoltarea economică a României (Economic Development of Romania), Bucharest: Editura Academiei, 2003, pp. 475-487.

21. Sammarra, A. and Belussi, F., 'Evolution and Relocation in Fashion-led Industrial Districts, Evidence from Two Case Studies', 2006, Entrepreneurship and Regional Development, vol. 18, no. 6, pp. 543-562.

22. Timişoara City Hall, 'Starea economică, socială şi de mediu a municipiului Timişoara' (Economic, Social and Environment Context in City of Timişoara), 2008, [Online] available at https://www.primariatm.ro/index.php?meniuId=2\&viewCat=1312, accessed on June 21, 2017.

\section{Internet sources:}

23. Lista Firmelor din România (List of Romanian Companies), [Online] available at https://www.listafirme.ro/, accessed on June 21, 2017.

24. National Institute of Statistics, [Online] available at insse.ro, accessed on June 21, 2017.

25. www.worldfootwear.com, accessed on June 21, 2017. 